\title{
ISRAEL SEEN FROM EGYPT Understanding the Biblical Text from Visuals and Methodology
}

\section{Kenneth A. Kitchen}

This study is in two parts: (i) Egypt as a source of illustration, primarily visual, serving as illuminative background to the biblical text; (ii) Egyptian (and allied) documentation as an exemplary (even, admonitory) paradigm in considering historical methodology and the Old Testament.

\section{Illustration}

1. Visual Illustration. Clearly, ancient (and sometimes modern) Egypt is the logical place in which to look for possible illustrations of those passages of the Old Testament set in Egypt or concerned with Egypt. One thinks immediately of the Joseph narrative and the account of the Exodus, besides later and briefer episodes. It is relatively easy to leaf through the publications of brightly-painted or carved Egyptian private tomb-chapels of the Old, Middle and New Kingdoms, c. 2600$1070 \mathrm{BC}$ (later material being sparser), and find scenes and details which, in principle, exhibit items identical in subjectmatter with features mentioned in the Old Testament. However, this tends to be done on rather haphazard lines, without much regard for the relative dates of the parallels adduced not to mention the enormous time-gap between the biblical text and modern parallels. Such haphazard selection of illustrations can be found in major modern compendia. ${ }^{1}$

While it is true that there are vast continuities across time, both during antiquity and from antiquity to the present, yet it is surely preferable to match as closely as possible, in time, the biblical and external data. Thus, for examples of the dress of Western Semites of the patriarchal age (still early 2 nd

\footnotetext{
${ }^{1}$ Such as J.B. Pritchard (ed.), The Ancient Near East in Pictures relating to the Old Testament (Princeton 1954) or in N. Hillyer et alii, Illustrated Bible Dictionary, I-III (Leicester 1980).
} 
millenium $B C$, despite unjustified carping), it is wholly proper to refer to the well-known wall-painting at Beni-Hasan showing just such people at that general period (19th century $\mathrm{BC})$, but not to Egyptian scenes of Canaanites of the later 2nd millenium BC (Eighteenth Dynasty and later), when fashions in dress had changed. ${ }^{2}$

However, it is often just not possible to achieve an exact time-match; nor is it always absolutely essential. The famous brickmaking scene in the tomb-chapel of the vizier Rekhmire, c. $1450 \mathrm{BC}$, is universally used to illustrate the brickmaking episodes in Exodus 1:11-14 and 5:6-19 in a milieu of up to 200 years later (early Ramesside). But there is no other such scene extant, hence for illustration we have no choice in the matter. ${ }^{3}$ Moreover, the use of hollow, rectangular wooden brick-moulds (as used in that scene) goes right through history from at least the 15 th century $B C$ to the 20 th century $A D$, so we have a very long continuity in usage which embraces the entire biblical period and well beyond it. ${ }^{4}$

\footnotetext{
${ }^{2}$ At Beni-Hasan, the men wear either short kilts or off-the-shoulder shifts, all in coloured wool; the ladies wear not dissimilar shifts, off the opposite (right) shoulder; cf. (older references) B. Porter \& R.L.B. Moss, Topographical Bibliography of Ancient Egyptian Hieroglyphic Texts, Reliefs, and Paintings (Oxford 1934) 146 top; Semite with donkey, the ladies, in colour, N. de G. Davies \& A.H. Gardiner, Ancient Egyptian Paintings (Chicago 1936) I, pls. 10,11; entire scene, small format, often reproduced; e.g., J.B. Pritchard (ed.), The Ancient Near East in Pictures relating to the Old Testament (Princeton 1954) fig. 3 (= idem, The Ancient Near East, [I], (Princeton 1958) fig. 2.) In later centuries, Canaanites often wear closer-fitting garments, long-sleeved to the wrists, spiral swathing around waist-to-knee, all of plain, not patterned cloth, or of quite different patterning. Cf. (e.g.) in Tomb 63 at Thebes (now British Museum No. 37991), in colour, Davies \& Gardiner, op. cit., I, pl. 42 (= Champdor, n.7 below, Part 1, 1953, 3rd plate); small-scale reproduction, Pritchard (ed.), The Ancient Near East in Pictures. . . (1954) fig.47 (= idem, The Ancient Near East, [I], (1958) fig.5).

${ }^{3}$ Full references for the Rekhmire scene are given by Porter and Moss,Topographical Bibliography, I:I (Oxford 1960) 211-12 (14),V; official publication, see N. de Garis Davies, The Tomb of Rekhmire (New York 1943) I, 54ff., II, pls.58-61, and idem, Paintings from the Tomb of Rekhmire at Thebes (New York 1935) pls.16-17. Innumerable other reproductions; for convenience cf. (e.g.): in Pritchard (ed.), Ancient Near East in Pictures, fig. 115b (= idem, The Ancient Near East. . ... II] (1958) fig.18).

${ }^{4}$ For the use and techniques of brickwork in ancient Egypt, see A.J. Spencer, Brick Architecture in Ancient Egypt (Warminster 1979); on Egyptian brickmaking as background to Exodus 1-5, cf. K.A. Kitchen, Tyndale Bulletin 27 (1976) 137-47. A typical Ramesside brick, with traces of chaff/straw in the British Museum
} 
A similar but converse situation applies to Joseph's installation as a high official of the pharaoh, with signet-ring and gold collar (Genesis 41:41-2). Here, our only group of pictorial illustrations (14th-13th centuries BC) falls at least three centuries or so after the patriarchal age, ranging from examples of the Amarna age to Ramesside occurrences under Sethos I (Tomb 106 at Thebes) and Merenptah (Tomb 23), 5 when we also possess a narrative allusion to these features at the appointment of the high priest Nebwenenef by Ramesses II (Tomb 157) 6

A clear Egypto-Semitic cultural continuum may be seen in Joshua 10:24, warrior-chiefs to put their feet on the necks of defeated Canaanite rulers, and in the allusion in Psalm 110:1 'your enemies your footstool'. Almost half a millenium before David (and 200 years before Joshua), we find a vivid pictorial example of this symbolic act under Amenophis II (c. 1420 BC). Shown as a young king seated on a nurse's lap, his feet rest upon humbled Canaanite chiefs. Actual footstools from the treasures of Tutankhamun's tomb (c. $1330 \mathrm{BC}$ ) bear symbolic figures of vanquished Canaanite and Nubian chiefs upon their upper surfaces, on which the young pharaoh's feet would rest when the footstools were in use. ${ }^{7}$ Here, we have an indubitable

(No. E 6020), see T.C. Mitchell, The Bible in the British Museum (London 1988) 40; traditional modern Egyptian brick-field, cf. A.R. Millard, Treasures from Bible Times, (Tring 1985) 75.

${ }^{5}$ Full references in Porter and Moss, op. cit. (n. 3 above), 221 (5) for Tomb 106; ibid., 39 (18), reward-scenes on same model as appointments. On scenes of reward and appointment (investiture) in the Amarna tombs, 14th century BC, cf. Kitchen, Oriens Antiquus 12 (1973) 240-1 (correcting the survey by D.B. Redford, A Study of the Biblical Story of Joseph (Genesis 37-50) (Leiden 1970) 208-26.

${ }^{6}$ Porter and Moss, op. cit., 267 (8); hieroglyphic text, Kitchen, Ramesside Inscriptions, III (Oxford 1978-80) 282-5; the scene and English translation, see Kitchen, Pharaoh Triumphant, Life E Times of Ramesses II (Warminster 1982) 46-7 and fig.6.

7Picture of Amenophis II, Theban Tomb 93 (Porter and Moss, op. cit., 92 (16); official publication, N. de G. Davies, The Tomb of Ken-amun at Thebes (New York 1930) I, pl. 9; II, pl. 9A (colour); see (also in colour), N. de G. Davies and A.H. Gardiner, Ancient Egyptian Paintings, I ,(Chicago 1936), pl. 29 (= A. Champdor, La peinture egyptienne ancienne (Paris 1954) I, 6th pl.). In line, W.M.F. Petrie, A History of Egypt, II, (London 1904) 154, fig.96. Footstools of Tutankhamun, see P. Fox, Tutankhamun's Treasure (Oxford 1951) pl.60 (and matching hassock, pl.61), and C. Desroches-Noblecourt, Tutankhamen (London 1963) colour-plate XI. Cf. also Kitchen, Ancient Orient \& Old Testament 
community of concept across both cultures. Many more examples could be given along these lines.

2. Verbal Expression. Direct illustration of biblical usage is not, of course, restricted to the pictorial realm. It occurs copiously in the realm of concepts and verbal idioms. Again, such parallels in usage may occur either close in time or spread across the centuries, showing considerable continuity in practice.

A peculiar detail showing long continuity in Egypt, with a reflex in the Hebrew Bible, concerns a particular euphemism. In 2 Samuel 12:14 there occurs the Hebrew idiom 'slighted the enemies of the Lord', in which 'enemies (of)' is a euphemistic inclusion. That it is so, and not simply a late, defensive gloss to the text, ${ }^{8}$ is clear from closely analogous Egyptian data. Some 600 years before David's day, precisely this idiom is attested in an Egyptian decree of the 17th-16th centuries BC from Koptos, ousting a man who 'rebelled against the enemies of his god'.9 These two examples (in 2 Samuel and from Koptos) no longer stand in isolation, with the discovery of further Egyptian examples of the New Kingdom (late 2nd millenium BC) and into the Late Period. ${ }^{10}$ So, in Egyptian, this idiom was stable in usage for a thousand years or more. There is no reason to imagine that it was any less so in West Semitic, it is merely the case that the data are so much sparser.

On a far broader front, the concept and usage of personification, as in Proverbs 9, is amply attested from the 3rd and 2nd millenia BC not only in Egypt but also right across the spectrum of cultures in the entire biblical Near East, giving a rich background. As typical examples have been given

(London 1966) 164-5.

${ }^{8}$ As is implied in commentaries oblivious to the data given here; cf. (e.g.) S.R. Driver, Notes on the Hebrew Text and Topography of the Books of Samuel (Oxford 1913) 292 (following Geiger), or R.P. Gordon, I \& 2 Samuel, A Commentary, (Exeter 1986) 259 (wrongly following RSV and McCarthy).

${ }^{9}$ First pointed out by R. Yaron, VT 9 (1959), 89-91, then by Kitchen, Ancient Orient \& Old Testament (1966) 166.

${ }^{10}$ See G. Posener, Zeitschrift für Aegyptischen Sprache 96 (1969), 30-5, on New Kingdom and Late Period examples; Demotic also yields a series of further examples. See J.F. Quack, Revue d'Egyptologie 40 (1989), 197-8. 
elsewhere, they will not be repeated here. ${ }^{11}$ Again, this whole field could be expanded in depth.

\section{Paradigms in Historical Method}

1. Evaluation of Narratives. One hardly needs to observe that, in Old Testament studies, there are considerable differences of opinion over how to treat biblical narratives, particularly those that deal with the pre-monarchy period. The somewhat naive assumption tends to be made that, because their format is 'annalistic', the books of Kings are more definitely 'historical' than narrative books about earlier periods (e.g., Genesis to Judges), which do not show such a format, nor (generally) so staccato a treatment of people and events. ${ }^{12}$

However, this is about as far as it goes. Apart from unsubstantiated guess-work about supposed 'saga',13 and tendentious comparisons between myths and the patriarchal narratives, ${ }^{14}$ almost no proper groundwork has been done on trying to set out verifiable criteria for assessing the historical quotient of ancient narratives. ${ }^{15}$ It requires consideration of the entire narrative material from the ancient Near East as well as in the Old Testament; the task is therefore considerable and far-reaching; it cannot, therefore, be pursued in this paper. But certain false assumptions common in biblical studies can be usefully weeded out, and better approaches be substituted.

\footnotetext{
${ }^{11}$ A variety given in Kitchen, Tyndale Bulletin 5/6 (1960), 4-6; for the ramifications of the concept in Egyptian iconography from c. 3000 BC downwards, see J. Baines, Fecundity Figures, (Warminster/Chicago 1985) 7ff., 17f., $19 \mathrm{ff}$.

${ }_{12}$ Precisely such an uncritical attitude (innocent of direct contact with any evidence to its contrary) is exemplified (e.g.) by H. Shanks, in H. Shanks (ed.), Ancient Israel, A Short History, (Washington 1988) xvii-xix.

${ }^{13} \mathrm{H}$. Gunkel, The Legends of Genesis (New York 1964) originally published (in German) in 1901 as the introductory survey in his commentary on Genesis. Contrast the points raised by R.N. Whybray, The Making of the Pentateuch (Sheffield 1987) 133-219, esp. 142ff.

${ }^{14}$ The classic case of picking in advance one's comparative material to achieve a desired result (i.e., select only myths and tales to compare with the patriarchal narratives, so they are myths too) is D. Irvin, Mytharion, the Comparison of Tales from the Old Testament and the Ancient Near East [Alter Orient und Altes Testament, 32] (Neukirchen-Vluyn 1978).

${ }^{15}$ Almost the sole exception being Kitchen, The Bible in its World (Exeter 1977) 59-68, which was too brief to do full justice to the matter.
} 
The patriarchs are a good case in point. On Genesis 1250 , the full arc of the rainbow of opinion in Old Testament studies runs all the way from regarding these texts as history to the last detail of our extant text, across to regarding them as totally fictional - in Wellhausen's memorable phrases as offering 'no historical knowledge', but 'projected back [from the monarchy period] into hoary antiquity like a glorified mirage' ${ }^{16}$ The patriarchal narratives are often lively and, to our modern eyes, picturesque, and are not confined to brief staccato accounts within rigid formulae as in Kings or Chronicles. But can this justify the fashion for dismissing these narratives and their characters, now current in the present 'Neo-Wellhausian' climate of biblical studies? Clearly, the existing narratives in Genesis 12-50 did not come from the patriarchs themselves - they are all dead by the end of Genesis 50. Also, the phrase 'the land of Rameses' (47:11) only became current from the 13th century $B C$, not earlier, and fell obsolete after the 12th century BC. So, the origins and history of what we now find in Genesis do lend themselves to enquiry. But speculation in a vacuum, or based on far-distant parallels such as Nordic sagas, is a dead end. We do better to turn to the biblical world itself, if we would seek for some kind of external, checkable controls to guide and assist our inquest.

Here, in Egypt (as elsewhere) there are useful data to this end. It is particularly instructive to look at such a work as the so-called 'Tales of the Magicians', largely (but not completely) preserved in Papyrus Westcar, ${ }^{17}$ a manuscript of $c$. $1600 \mathrm{BC}$, in the Hyksos period, just before Egypt emerged into the New Kingdom era of great political power. Its four stories narrate marvels supposedly done by four learned magicians at the courts of four kings of the Third and Fourth Dynasties about a thousand years (c. 2700-2500 BC) before the date of the

${ }^{16} \mathrm{Cf}$. full citation in English, ibid ., 57, 142, n.2 (translation, KAK); otherwise, T. Wellhausen, Prolegomena to the History of Ancient Israel, 1885 (repr. 1957), 318-9 (German in idem, Prolegomena zur Geschichte Israels, 6th ed., (1927) 316). ${ }^{17}$ Hieroglyphic text now conveniently available in A.M. Blackman, ed. by W.V. Davies, The Story of King Kheops and the Magicians (Reading 1988); there are many translations, e.g., W.K. Simpson (ed.), The Literature of Ancient Egypt, 2nd ed., (New Haven/London 1973) 15-30, or M. Lichtheim, Ancient Egyptian Literature, A Book of Readings, I: The Old and Middle Kingdoms (Los Angeles 1973) 215-22. 
present narrative. The first tale is almost totally lost, the second damaged, the third complete, and the fourth lacks the ending. The kings are Djoser, Nebka, Snofru, and Khufu. At the court of Khufu, each of his sons in turn ([Kawab or Redjedef?], Khafre, Bauefre, Hardjedef) tells a tale of a great magician at the court of one of Khufu's predecessors, until Hardjedef caps their efforts by actually producing a magician to perform before his father and the court. The deeds of all the four magicians remain strictly in the domain of the marvellous. What happened under Djoser at the hands of [Imhotep] is lost. Under Nebka, the magician Weba-oner makes a wax crocodile which, at the magic word, suddenly becomes a full-sized real crocodile, obeying its master's command, and can hold a guilty man at the bottom of a pool for a week without either man or beast drowning! Under Snofru, the skilled Djadjaemankh can roll back the waters of a pleasure-lake just like an eiderdown, to recover a dropped amulet. Finally, before Khufu, the magicianscholar Djedi ${ }^{18}$ can rejoin by magic spell the severed head and body of a goose and of a bull, causing the parts to come together from opposite sides of a room to link up alive again. All these incidents are, transparently, purest fiction, and from the time of the story-writer, they are (to resume our Wellhausenian phrase) projected back into hoary antiquity, in this case by 1,000 years. Are these stories, then, of no historical value, and are their characters fictional, as would be inferred for the biblical patriarchs? On the basis of original evidence, the answer is 'no'. On the evidence of original monuments, kinglists, etc., we know that all four kings were real, historical rulers of the Third and Fourth Dynasties; three of them (and most likely, all four ${ }^{19}$ ) also occupied the throne in the order in

\footnotetext{
${ }^{18} \mathrm{~A}$ nice touch is that, when Djedi sailed to the capital to perform before the pharaoh, he needed two boats: one for himself and family, and one for his books! Scholars' logistical problems have not changed much....!

${ }^{19}$ The only doubt affects Nebka. One king Nebka (if he is the Horus-king Sanakht) preceded Djoser, not following him as in our tale; but one of Djoser's successors in the obscure middle part of the Third Dynasty appears to have been the king Nebka(re) of the Saqqara king-list, and he may have been the ruler intended. The massive tomb-substructure at Zawiyet el-Aryan of a Nebka(re) is certainly later than Djoser. (On Nebkare's name there, see J. Cerny, Mitteilungen, Deutschen Archäologischen Instituts, Abt. Kairo 16 (1958) 25-9; the demurral by A. Dodson, Zeitschrift f. Aeg. Sprache 108 (1981) 171, is
} 
which the tales name them. The sons of Khufu named are all historical; Khafre succeeded him after the short reign of his brother Redjedef (teller of the first tale?), Bauefre is otherwise attested, as is Hardjedef who, in his own right, attained fame as the author of a wisdom-book, fragments of which are extant in later copies. So, both the kings and princes are all strictly historical characters, and rightly set in order in these tales of a millenium later than their time. Of the four magicians, much less can be said, as is always the case with private individuals in contrast to royalty. [Imhotep], if named, is certainly known from a contemporary monument of Djoser's time, as well as in later epochs. Weba-oner remains obscure. Djadjaemankh is a modernised form ${ }^{20}$ of Tepemankh, a name typical of the Old Kingdom, the period in which the tales are set;, ${ }^{21}$ Djedi, both as a name and as an abbreviation for longer names with this element is, again, primarily a name of the Old Kingdom. ${ }^{22}$ So, although only Imhotep is historically attested here, two of the other three bear names that reach straight back into the requisite period, and could reflect real officials of that time. There is nothing anachronistic here, other than substituting one word for 'head' for another.

In other words, beyond any doubt, this popular tale of the 16 th century BC (marked by language-characteristics of that time) preserved the memory of four ruling kings, in their right order, and of four principal sons of Khufu, and certainly of private names (and possibly officials) of that age within the matrix of its spiel of marvels. Also, the final tale includes what was cast as a prediction to Khufu of the birth of babes who would become the first three kings of the next (Fifth) Dynasty, giving him a Herod-like interest in their possible suppression. The babies are born in the order, and with the names, User-ref, Sah-re, Kaku, who are transparently a reference to User-kaf, Sahu-re and Kakau, the known first

unconvincing.

${ }^{20} \mathrm{Tep}$ is the older word for 'head'; it was later increasingly replaced by djadja; ending up as Coptic djodj.

${ }^{21}$ References, H. Ranke, Die ägyptischen Personennamen, I, Hamburg, n.d., 380:2.

${ }^{22}$ Cf. Ranke, op. cit., 412:17-413:5, esp. 412:20 (Old Kingdom; the occasional early Middle-Kingdom example). 
three kings of the Fifth Dynasty, and in that order. And two of the three were actually brothers. So, again, the popular tale has retained historical data with very little distortion across the elapsed millenium. ${ }^{23}$

The significance of this situation for evaluating the patriarchal narratives should be obvious, especially in the light of the known status of those narratives - on a basis of verifiable fact - as coming in between historical texts and historical legends about real people, being closer to the first of these two classes, and having practically nothing in common with the third class of text, pure fiction. ${ }^{24}$

The significance of such data is just this. That however fictional in content some Old Testament scholars consider the patriarchal narratives, the fact remains that (precisely as in Papyrus Westcar) we have no factual warrant whatsoever to doubt $a$ priori that they feature real individuals (Abra(ha)m, Isaac, Jacob, etc.), and in their correct sequence. The more so, as these narratives are almost wholly lacking in the kind of fairy-tale features found in Papyrus Westcar.

On a smaller scale, these considerations are reinforced by other literary narratives concerned with just one person or period. For example, the Ramesside Papyrus Harris 500 contains the remains of the tale of The Capture of Joppa, set 200 years earlier in the time of Tuthmosis III, c. $1450 \mathrm{BC}$. It tells of how, by smuggling in a body of soldiery (by an 'Alibaba' stratagem), a general Thuty captured the Canaanite town of Joppa for his king. ${ }^{25}$ Thuty, hero of the tale, is decidedly historical (as is his master, Tuthmosis III, attested by numberless monuments); a gold vessel presented to Thuty by the king is among the many Egyptian treasures of the Louvre in

\footnotetext{
${ }^{23}$ Significantly, tales that are totally fictional regarding characters tend to feature anonymous characters (so, the Shipwrecked Sailor; the Foredoomed Prince; the Herdsman and a Goddess, etc.), or clear personifications (e.g., Truth and Falsehood, in the Blinding of Truth), or feature deities but thinly disguised (Tale of Two Brothers). The same happens in Mesopotamia, cf. Kitchen, The Bible in its World (Exeter 1977) 63.

${ }^{24}$ For a compact exposition of the basic facts available, see Kitchen, ibid., 61-5

${ }^{25}$ Hieroglyphic text, A.H. Gardiner, Late-Egyptian Stories (Brussels 1932) xii, 82-5; translation, cf. W.K. Simpson (ed.), The Literature of Ancient Egypt, 2nd ed., (New Haven/London 1973) 81-4; also, J.A. Wilson, in J.B. Pritchard (ed.), ANET, 22.
} 
Paris. ${ }^{26}$ It is even conceivable that this gift actually commemorated some such deed of derring-do; but, naturally, that can only be speculation. But, again, a popular tale kept memory of historical characters who do belong together. While this paper is professedly concerned with Egyptian contributions to its theme, it is important to underline the fact that across the Near East, Mesopotamia offers the same phenomena. The tale of 'The King of Battle' tells of the ancient monarch Sargon of Akkad (c. 2300 BC) of almost a millenium before our copy (c. $1340 \mathrm{BC}$ ) invading Asia Minor to help the merchants of Purushkhanda against their oppressor. En route, he must overcome great obstacles: not only thorns and forests, but also blocks of lapis-lazuli and gold cumber his way!27 Again, however fantastic the gold and lapis barriers might be, Sargon of Akkad himself is immovably historical (original texts, and copies of others), Purushkhanda is a known place from other and authentic sources, and, if not yet attested there so early, Mesopotamian merchants did operate in Asia Minor. Again, people and features can be preserved perfectly well in the memory of story-telling tradition centuries afterwards. Why should it be any different for the Hebrew patriarchs? Particularly as, in their case, there is a whole series of factual indications that converge to place them firmly in the early 2 nd millenium $B C$, despite claims to the contrary. ${ }^{28}$

\footnotetext{
${ }^{26}$ N.713, references, Porter and Moss, Topographical Bibliography. . . , I:l, 23f.; text, K. Sethe, Urkunden der 18. Dynastie (Urk. IV) (Leipzig, Berlin/Graz, 1927/1961) 999, No.295; translated, A. Burkhardt et al., Urkunden der 18. Dynastie, Übersetzung zu den Heften 5-16 (Berlin 1984) 374-5.

27 Published by E.F. Weidner, Der Zug Sargons oon Akkad nach Kleinasien (Leipzig 1922) cf. W.G. Lambert, Archio für Orientforschung 20 (1963), 161f.; summary, C.J. Gadd, in Cambridge Ancient History, 3rd ed.,I:2 (Cambridge 1971) 442-3.

${ }^{28}$ The position is given fairly and factually in Kitchen, The Bible in its World (1977) 68-74 (pace T.L. Thompson, J. Van Seters, etc.), with appropriate references. Note also that the specifically early-2nd-millenium date for 'Amorite-Imperfective' type names (like Jacob, Isaac, Joseph, etc.) is now based on overwhelming evidence; see my paper, 'New Directions in Biblical Archaeology: Historical and Biblical Aspects', to appear in J. Amitai (ed.), [IInd International Congress on Biblical Archaeology Volume] (Jerusalem 1991) in press, pace P. Kyle McCarter, in H. Shanks (ed.), Ancient Israel, A Short History. (Washington, 1988) 1-29, e.g. 11, 28; contrast already, Kitchen, Themelios 15/1 (Oct. 1989), 25-6. Palestinian archaeologists are beginning cautiously to feel their way back to a patriarchal age in the early 2 nd
} 
2. Theological Bias. All too often, Old Testament scholars express their reservations about biblical narratives (even in Kings; and not least in Chronicles), implying or expressing a judgement that either (i) we cannot properly know what happened because the theological Tendenz of the ancient writer has coloured or warped his presentation of historical fact; or (ii) the ancient author, in order to express his Tendez, has actually manufactured 'history' for the purpose of getting his message across. So-called Deuteronomic theological writing often stands accused of such procedures, for example.

However, biblical scholars go on to present this element of Tendenz as though it was a fault peculiar solely to the Old Testament writers. Which, in the light of the known facts, is quite naive. No known author, ancient or modern, ever writes but from some basis of assumptions (not least Old Testament scholars themselves!); and all across the biblical world, ancient authors not only had particular viewpoints that they started from, but often set about propagating their viewpoint(s) with as much vigour as any Deuteronomist. The matter is a banality. That all being said, questions properly remain to be answered. Does this universal attestation of Tendenz justify the reservations of Old Testament scholars in the two respects mentioned above? Did the ancients falsify history wholesale, in order to propagate their views? Again, it is instructive to turn to Egypt, and to consider biblical texts in the light of Egyptian presentations of historical events.

It is common, for example, for biblical scholars to assume that the book of Joshua presents an outright Israelite conquest of Canaan (ignoring Ch. 13, of course!), in order to contrast it with the slower occupation of Canaan as seen in the book of Judges, and then to dismiss Joshua as a (late) theological construct, particularly if the somewhat elusive archaeological data can be interpreted to reach the same conclusion.

Joshua is undoubtedly a book written with didactic motives-and so is Judges! - but scrutiny of its style and content

millenium BC; cf. (e.g.) A. Mazar, Archaeology of the Land of the Bible (New York 1990) 224-6, and already earlier, the judicious review by W.G. Dever, in J.H. Hayes, J.M. Miller (edd), Israelite \& Judaean History (London/Philadelphia 1977) 77-120, esp. 99-120. 
should be conducted in the light of Ancient Near Eastern canons of composition and presentation. Thus, it maximises on a leader's success through his obedience, pointing-up the results of disobedience in contrast (e.g., Ai, first attack). Those who accept the biblical writer's theological stance would agree with this theological statement of 'cause-and-effect', while an observer not committed to that stance would simply note the fervent beliefs of those involved, their successes (e.g., Jericho, Hazor), and failures (e.g., Ai, first time), in just the same way that all modern observers note the historical data in the records of Egyptian or Assyrian kings, without sharing their beliefs in the power of Ashur, or in the value of strict obedience to Amun. Again, when one scrutinises the Joshua narratives closely, only three locations are actually claimed to have been destroyed (Jericho, Ai, Hazor), out of twenty or thirty kinglets defeated or slain. And of those three places destroyed, only the immediate area of two (Jericho, Ai) close to the Jordan valley was actually occupied then and there. So much for the claim of a 'biblical' theme of wholesale and outright conquest (and implied universal settlement). . . Thus, behind the theology and the rhetorical style, we have in hard terms a quite limited set of historical acts: three places destroyed (two, not so far from the base-camp), various hostile chiefs slain in rapid raids, and the land overall assigned in theory for future occupation but not possessed. Glimpses of the settling/possessing process (but without much continuous narrative) can be seen in Judges, whose presentation follows different lines.

If we turn to Egypt's wars in Canaan, we may see rather similar things. The various series of war-scenes inscribed on temple walls at Karnak by Sethos I and Ramesses II, and at Medinet Habu by Ramesses III, plus the Battle of Qadesh presentations by Ramesses II - all these, without exception, are theological presentations of their acts, in terms of Amonist imperial theology. The pharaoh goes on campaign at the behest of Amun, defender of Egypt, quelling the rebellious, in terms that show no less Tendenz than any supposed Deuteronomic writer. Yet, despite this, we can read off the essential historical quotient from these scenes and texts. This remains true, even when a political defeat is presented as a 
royal triumph for the gods, as in the case of the Battle of Qadesh. Rigorous scrutiny of texts and scenes suggests that Ramesses II tells no whopping lies, and does not manufacture history - but he does present it to Egypt's and his advantage. But this fact can be perceived and allowed-for. Thus, he at no point claims to have captured Qadesh, for example. His most blatant show of Tendenz is when he portrays the Hittite king Muwatallis as suing for peace after the two days of battle. However, a knowledge of the ways of Hittite policy and of Egyptian rhetoric would suggest that the historical reality behind Ramesses' boast is that the Hittite king did in fact send a proposal of peace to Ramesses II, but in terms of keeping the status quo ante bellum, in accord with the treaty previously signed by their predecessors. ${ }^{29}$ One may conduct enquiries of this kind using the Mesopotamian historical sources as basis, where the theology of Ashur or Marduk governs the presentations, for example.

In short, when reading all the other literatures of the biblical world, we find deterministic theologies in command, as much as in any biblical writing; in those cases, it is usually perfectly feasible to discern the historical basis, and there is no factual reason for reading the biblical writings any differently. Did the ancients 'manufacture' history? One may doubt it. Sometimes they re-used in a later reign some historical record from an earlier period, ${ }^{30}$ but they did not invent 'history' out of thin air.

\section{Conclusions.}

Here we may be brief. The first (on pictorial illustration) is that we have to be careful, even choosy, over comparisons between biblical texts and visible pictorial records, wary of change, as well as noting genuine continuities.

\footnotetext{
${ }^{29}$ Those with a taste for historical appraisal of such theologically-motivated non-biblical sources might care to read Ramesses II's actual accounts from his point of view (accessible in translation, in Sir A.H. Gardiner, The Kadesh Inscriptions of Ramesses II (Oxford 1960), and then compare them with a modern assessment of the famous battle and its consequences (e.g., Kitchen, Pharaoh Triumphant, the Life \& Times of Ramesses II (Warminster 1982) 5364).

${ }^{30}$ As did Pepi II a Libyan war-scene of Sahure; references, Kitchen, Ancient Orient \& Old Testament (London 1966) 30 \& n.36.
} 
The second is that various assumptions that are commonplace in biblical scholarship regarding historicity, theological impact, etc., are in urgent need of drastic reappraisal in the light of actual, attested usage in the biblical world itself. Ancient theological writers were perfectly capable of using history without abusing its facts. An immense amount of constructive work remains to be attempted in this realm. 